\title{
Responsivitas Penyelenggaraan Pelayanan Publik di Dinas Kependudukan dan Pencatatan Sipil Kabupaten Bone
}

\section{Responsiveness of Public Service Delivery at the Population and Civil Registration Office of Bone Regency}

\author{
Rasdiana $^{1}$, Riski Ramadani ${ }^{2}$ \\ Universitas Muhammadiyah Makassar ${ }^{12}$ \\ J1. Sultan Alauddin No. 259, Makassar, Sulawesi Selatan \\ rasdianaras@unismuh.ac.id ${ }^{1}$
}

Naskah diterima tanggal 28 Oktober 2021. Naskah direvisi tanggal 2 Desember 2021.

Naskah disetujui tanggal 29 Desember 2021.

\begin{abstract}
Abstrak
Responsivitas sebagai salah satu indikator dalam pelayanan publik yang berkaitan dengan daya tanggap aparatur negara terhadap kebutuhan masyarakat yang membutuhkan pelayanan sebagaimana yang diatur dalam perundang-undangan. Penelitian ini bertujuan untuk menjelaskan responsivitas penyelenggaraan pelayanan publik pada Dinas Kependudukan dan Pencatatan Sipil Kabupaten Bone. Penelitian ini menggunakan pendekatan kualitatif dengan jenis deskriptif. Adapun sumber penelitian terdiri dari data primer yaitu wawancara mendalam dengan informan, informan berasal dari aparat pemerintah di Dinas Kependudukan dan Pencatatan Sipil Kabupaten Bone serta masyarakat sedangkan data sekunder berasal dari dokumentasi. Data penelitian dikumpul dengan observasi partisipasi. wawancara mendalam dan dokumentasi. Data tersebut dianalisis dengan teknik reduksi data, penyajian data dan studi dokumentasi. Kemudian dilakukan pengabsahan data dengan triangulasi sumber, tiangulasi teknik dan triangulasi waktu. Hasil penelitian ini menunjukkan kemampuan merespon masyarakat sudah baik terlihat dari penggunaan nomor handpone Kepala Dinas sebagai nomor publik, kecepatan melayani kurang baik diakibatkan oleh jaringan yang biasa eror dan aparatur pemerintah kurang dibandingkan dengan masyarakat yang banyak, ketepatan melayani sudah baik sesuai dengan standar operasional prosedur, kecermatan melayani sudah baik karena telah berbasis elektronik, ketepatan waktu pelayanan yaitu waktu proses sampai verifikasi harus sesuai jadwal, kemampuan menaggapi keluhan sudah baik karena telah menerima pengaduan dan pengisian Google Form yang diterapkan Dinas Kependudukan dan Pencatatan Sipil Kabupaten Bone.
\end{abstract}

Kata kunci: Responsivitas; Penyelenggaraan; Pelayanan Publik

\footnotetext{
Abstract

Responsiveness as an indicator in public services related to the responsiveness of the state apparatus to the needs of the people who need services as regulated in the legislation.
} 
Therefore. This study aims to explain the responsiveness of public service delivery at the Department of Population and Civil Registration of Bone Regency. This study uses a qualitative method with a descriptive type while the research sources consist of primary data and secondary data, the determination of informants also comes from government officials at the Population and Civil Registration Office of Bone Regency and the community. Research data were collected by Participation Observation. in-depth interviews and documentation studies. The data were analyzed by data reduction techniques, data presentation and documentation studies. Then validated the data by source triangulation, technique mastulation and time triangulation. The results of this study indicate that the ability to respond to the community is good, as can be seen from the use of the Head of Service's mobile number as a public number, the speed of service is not good due to the usual network errors and less government apparatus compared to many people, the accuracy of serving is good in accordance with standard operating procedures, Accuracy in serving is good because it is electronically based, timeliness of service, namely processing time until verification must be on schedule, ability to respond to complaints is good because it has received complaints and filled out Google Forms implemented by the Population and Civil Registration Office of Bone Regency.

Keywords: Responsiveness; Maintenance; Public service

\section{PENDAHULUAN}

Kepuasan masyarakat merupakan salah satu bentuk keberhasilan suatu instansi atau organisasi dalam menyelenggarakan kegiatan pemerintahan berdasarkan prinsip efektif, efisien, inovasi dan komitmen. Salah satu bentuk kepuasan masyarakat yang paling utama ialah dalam hal pelayanan publik. Pelayanan publik merupakan suatu kegiatan atau proses respon aparatur sipil terhadap masyarakat yang menyangkut kepentingan administrasi publik. Salah satu bentuk pelayanan publik dapat dilihat berdasarkan isi Pasal 1 Ayat 1 Undang-Undang Nomor 25 Tahun 2009 Tentang Pelayanan Publik, yang berbunyi "pelayanan adalah kegiatan atau rangkaian kegiatan dalam rangka pemenuhan kebutuhan pelayanan sesuai dengan peraturan perundang-undangan bagi setiap warga negara dan penduduk atas barang, jasa, dan/atau pelayanan administratif yang disediakan oleh penyelenggara pelayanan publik".

Pelayanan publik merupakan salah satu bentuk responsivitas aparatur sipil dalam penyelenggaraan administrasi negara Kartini et al., (2020). Pelayanan publik dapat diartikan sebagai pemberian layanan keperluan orang atau masyarakat yang mempunyai kepentingan pada organisasi itu sesuai dengan aturan yang telah ditetapkan. (Kurniawan dalam Mahsyar, 2011). Responsivitas merupakan kemampuan pemerintah untuk menunjukkan keselarasan antara program dan kegiatan serta mengembangkan programprogram sesuai dengan kebutuhan dan aspirasi masyarakat. Dengan demikian, semakin banyak program yang diselenggarakan sesuai dengan kebutuhan dan aspirasi masyarakat, 
maka semakin baik responsivitas aparat sipil tersebut.

Responsivitas aparatur sipil terhadap kebutuhan dan aspirasi masyarakat merupakan suatu bentuk pelaksanaan fungsinya sebagai pelaksana kegiatan pembangunan dan pelayanan demi mewujudkan kesejahteraan masyarakat. Pelayanan publik sangat terikat dengan prinsip, aturan dan prosedur yang mengikat.

Tidak dapat dipungkiri bahwa pelayanan publik berdasarkan pandangan masyarakat saat ini belum sesuai dengan keinginan masyarakat karena pelayanan saat ini dinilai berbelit-belit dan tidak adanya penyampaian prosedur pelayanan yang jelas sehingga masyarakat terkadang bingung dengan Standar Operasional Prosedur pelayanan. Selain itu, adanya sistem kekeluargaan yang terjadi pada pelayanan yang membuat sebagian kecil masyarakat merasa diperlakukan kurang adil oleh pelayan publik.

Responsivitas penyelenggaraan pelayanan publik telah diteliti terlebih dahulu oleh Herdini \& Widiyarta (2020), yang mana responsivitas pelayanan pada Perusahaan Daerah Air Minum Kabupaten Nganjuk belum berjalan secara optimal dikarenakan dalam hal merespon pelanggan, petugas pelayanan belum memberikan respon yang baik ketika pelanggan menyampaikan keluhannya. Dalam hal pelayanan dengan tepat waktu, petugas tidak bisa memikan informasi mengenai kepastian waktu dan keterlambatan penanganan padahal informasi tersebut sangat penting disampaikan.

Dalam mengukur responsivitas pelayanan publik, Zeithaml, dalam Rismawati, dkk (2015) menyatakan bahwa responsivitas adalah kerelaan untuk menolong customers dan menyelenggarakan pelayanan secara ikhlas, serta kemauan untuk membantu konsumen bertanggung jawab terhadap mutu layanan yang diberikan. Adapun indikator responsivitas menurut Zeithaml, dkk dalam Rismawati, dkk (2015), sebagai berikut :1) Kemampuan Merespon Masyarakat, 2) Kecepatan Melayani, 3)Ketepatan Melayani, 4) Kecermatan Melayani, 5) Ketepatan Waktu Pelayanan, dan 6) Kemampuan menanggapi Keluhan.

Adapun penelitian-penelitian terdahulu yang relavan dalam mendukung penelitian ini, diantaranya:

\section{Tabel 1}

Penelitian Terdahulu

\begin{tabular}{|l|l|l|l|}
\hline No & \multicolumn{1}{|c|}{ Nama/Tahun } & \multicolumn{1}{c|}{ Judul } & \multicolumn{1}{c|}{ Hasil Penelitian } \\
\hline 1 & Fega Herdini, Agus & Responsivitas Pelayanan & Masih terdapat beberapa \\
& Widiyarta & Publik Dalam & kekurangan seperti kurangnya \\
& 2020 & $\begin{array}{l}\text { Menangani Keluhan } \\
\text { pelanggan Publik Dalam }\end{array}$ & $\begin{array}{l}\text { respon petugas dalam merespon } \\
\text { keluhan pelanggan melalui }\end{array}$ \\
\hline
\end{tabular}




\begin{tabular}{|c|c|c|c|}
\hline & & $\begin{array}{l}\text { Menangani Keluhan } \\
\text { Pelanggan di Perusahaan } \\
\text { Daerah Air Minum } \\
\text { (PDAM) Kabupaten } \\
\text { Nganjuk }\end{array}$ & $\begin{array}{l}\text { telepon, masih terdapat kendala } \\
\text { yang dialami petugas seperti } \\
\text { jumlah petugas teknis yang } \\
\text { tersedia dilapangan. }\end{array}$ \\
\hline 2 & $\begin{array}{l}\text { Donny Sumarsono, } \\
\text { Dra. Meirinawati, } \\
\text { M.AP. } \\
2016\end{array}$ & $\begin{array}{l}\text { Responsivitas Pelayanan } \\
\text { Publik di Rumah Sakit } \\
\text { Umum Daerah DR. } \\
\text { Mohammad Soewandhie } \\
\text { Surabaya. }\end{array}$ & $\begin{array}{l}\text { Hasil penelitian menunjukkan } \\
\text { bahwa dari } 6 \text { indikator yang } \\
\text { digunakan masih terdapat } \\
\text { beberapa kekurangan seperti, } \\
\text { merespon setiap } \\
\text { pelanggan/pemohon yang ingin } \\
\text { mendapatkan pelayanan, ada } \\
\text { yang kurang tanggap, } \\
\text { petugasnya kurang baik dalam } \\
\text { melayani pengaduan pasien } \\
\text { kritis, ada juga keluhan tersebut } \\
\text { dapat berupa kebersihan yang } \\
\text { ada dirumah sakit ini lebih } \\
\text { ditingkatkan lagi } \\
\text { kebersihannya. } \\
\text { Petugas/aparatur melakukan } \\
\text { pelayanan degan cepat, ada } \\
\text { juga petugas yang lamban } \\
\text { menangani pasien yang sedang } \\
\text { kritis. }\end{array}$ \\
\hline 3 & Suci Apriliya 2019 & $\begin{array}{l}\text { Responsivitas dan } \\
\text { pelayanan Publik di } \\
\text { Kantor Dinas } \\
\text { Kependudukan dan } \\
\text { Pencatatan Sipil } \\
\text { Kabupaten Gowa. }\end{array}$ & $\begin{array}{l}\text { Tingkat responsivitas pada } \\
\text { kantor Dinas Kependudukan } \\
\text { dan Pencatatan Sipil kabupaten } \\
\text { Gowa dikategorikan baik. } \\
\text { Walaupun masih ada beberapa } \\
\text { kekurangan dalam pelayanan } \\
\text { dan masih perlu melakukan } \\
\text { perbaikan dan meningkatkan } \\
\text { kinerja pelayanan seperti pada } \\
\text { aspek ketepatan waktu yang } \\
\text { kurang diterapkan pegawai } \\
\text { sehingga menghambat } \\
\text { pelayanan yang dibutuhkan } \\
\text { oleh masyarakat sehingga } \\
\text { terwujudnya pelayanan yang } \\
\text { prima. }\end{array}$ \\
\hline
\end{tabular}

Sumber: Data diolah oleh penulis, 2021

Penelitian pertama lebih berfokus pada responsivitas terhadap keluhan pelanggan dengan menggunakan enam indikator responsivitas menurut Zeithaml yaitu merespon setiap pelanggan, kecepatan pelayanan, kecermatan petugas, ketepatan waktu pelayanan dan petugas merespon semua pelanggan. Meski sama-sama berfokus pada 
responsivitas terhadap keluhan, tetapi pada penelitian kedua memilih lokus di Rumah Sakit sehingga yang menjadi objek penelitian adalah pasien. Selanjutnya penelitian ketiga berfokus pada responsivitas pelayanan publik dimana responsivitas pegawai sangat mempengaruhi efektivitas pelayanan publik.

Berdasarkan beberapa hasil penelitian terdahulu di atas, maka dapat disimpulkan bahwa penelitian di atas memiliki kesamaan dengan penelitian yang akan dilakukan oleh penulis yaitu membahas mengenai responsivitas pelayanan. Namun pada penelitian ini lebih berfokus pada responsivitas penyelenggaraan pelayanan publik pada Dinas Kependudukan dan Pencatatan Sipil. Kantor Dinas Kependudukan dan Pencacatan Sipil Kabupaten Bone telah menerapkan keharusan aparatur untuk memberikan pelayanan prima kepada masyarakat. Di Kabupaten Bone, semua masyakarat harus memiliki Kartu Tanda Penduduk elektronik (KTP-el) yang menjadi bukti bahwa orang tersebut diakui sebagai penduduk di Kabupaten Bone yang berdasarkan UU Nomor 24 Tahun 2013.

Berdasarkan hasil investigasi peneliti kepada masyarakat mengenai respon aparat di dinas tersebut ditemukan bahwa kurangnya respon aparat terhadap keluhan dan lambannya penyelesaian administrasi menyebabkan masalah yang kompleks terhadap pelayanan di Dinas Kependudukan dan Pencatatan Sipil Kabupaten Bone sehingga peneliti tertarik untuk melakukan penelitian dengan judul "Responsivitas Penyelenggaraan Pelayanan Publik di Dinas Kependudukan dan Pencatatan Sipil Kabupaten Bone".

\section{TINJAUAN PUSTAKA}

A. Konsep dan teori

\section{Good Governance}

Good Governance merupakan salah satu isu yang palimg mengemuka dalam pengelolaan pemerintah ini. Governance terjadi seiring dengan gerakan reformasi dalam upaya mengembalikan kepercayaan masyarakat, terutama sejak kemunduran kinerja ekonomi nasional yang kita alami. Secara konseptual "good" dalam bahasa Indonesia "baik" dan "governance" adalah "kepemerintahan". 
Menurut LAN (Lembaga Administrasi Negara) dalam Suwanda (2019), mengemukakan arti good dalam good governance mengandung dua arti yaitu sebagai berikut.

a. Nilai yang menjunjung tinggi keinginan/kehendak rakyat dan nilai yang dapat meningkatkan kemampuan rakyat dalam pencapaian tujuan (nasional) kemandirian pembangunan berkelanjutan dan keadilan sosial

b. Aspek fungsional dari pemerintahan yang efektif dan efisien dalam pelaksanaan tugasnya mencapai tujuan tersebut.

2. Pelayanan Publik

Pelayanan publik saat ini menjadi bagian kebutuhan setiap masyarakat. Setiap birokrasi publik perlu berupaya untuk memberikan kualitas pelayanan yang terbaik kepada masyarakat pengguna (Syahruddin et al., 2020).

Menurut Kotler dalam Nurdin (2019), pelayanan adalah setiap kegiatan yang menguntungkan dalam suatu kumpulan atau kesatuan dan menawarkan kepuasan meskipun hasilnya tidak terikat pada suatu produk secara fisik. Kemudian Sampara berpendapat bahwa pelayanan adalah suatu kegiatan atau urutan kegiatan yang terjadi dalam interaksi langsung antar seseorang dengan orang lain atau mesin secara fisik dan menyediakan kepuasan pelanggan.

Menurut Soetopo dalam Kairupan (2015), pelayanan adalah suatu usaha untuk membantu menyiapkan (mengurus) apa yang diperlukan orang lain. Pelayanan juga dapat disebut suatu proses bantuan kepada orang lain dengan caracara tertentu yang memerlukan kepekaan dan hubungan interpersonal agar terciptanya kepuasan dan keberhasilan.

\section{Definisi Responsivitas}

Menurut Sugiandi dalam Herdini \& Widiyarta (2020), responsivitas merupakan suatu konsep yang menyangkut kemampuan aparatur negara dalam menghadapi dan mengantisipasi aspirasi baru, perkembangan baru, tuntutan baru, dan pengetahuan baru, sehingga suatu birokrasi harus merespon secara cepat agar tidak tertinggal dalam menjalankan tugas dan fungsinya sebagai penyedia pelayanan.

a. Indikator Responsivitas 
Zeithaml, dkk dalam Rismawati, dkk (2015) menjelaskan secara rinci dan menyebutkan bahwa responsivitas termasuk ke dalam salah satu dimensi kualitas pelayanan publik, dimana dalam responsivitas sendiri terdiri dari atas beberapa indikator, yaitu:

1. Kemampuan Merespon Masyarakat

Setiap masyarakat memiliki karakter yang berbeda-beda, maka dari itu sebagai petugas layanan harus mengetahui bagaimana agar dapat bersikap dan berkomunikasi dengan baik dan sopan terhadap masyarakat.

2. Kecepatan Melayani

Pelayanan yang cepat dimaksudkan dengan meliputi kesigapan dan ketulusan petugas dalam menjawab pertanyaan atau permintaan dari masyarakat.

3. Ketepatan Melayani

Pelayanan dengan tepat yaitu dalam melayani jangan sampai terjadi kesalahan baik dalam hal pekerjaan maupun pembicaraan, dalam artian ini pelayanan yang diberikan oleh petugas harus sesuai dengan keinginan masyarakat.

4. Kecermatan Melayani

Kecermatan dalam memberikan pelayanan perlu diperhatikan supaya tidak terjadi kesalahan yang bisa merugikan masyarakat. Pelayanan dengan cermat yaitu petugas selalu fokus dan sungguh-sungguh dalam melakukan penyampaian pelayanan serta dalam melayani kebutuhan masyarakat.

5. Ketepatan Waktu Pelayanan

Maksud dari pelayanan dengan waktu yang tepat yaitu petugas dalam melayani masyarakat diharapkan pelaksanaan pelayanannya dapat diselesaikan dalam kurun waktu yang telah ditentukan.

6. Kemampuan Menanggapi Keluhan

Setiap pimpinan unit penyelenggara pelayanan publik wajib dalam menyelesaikan setiap laporan atau pengaduan maupun keluhan masyarakat mengenai ketidakpuasan dalam pemberian pelayanan sesuai dengan kewenangannya. Hal ini dilakukan agar supaya pelanggan dapat 
memperoleh kepastian waktu pelayanan yang akan diterimanya.

b. Responsivitas Pelayanan Publik

Reponsivitas pelayanan publik sangat diperlukan, karena sebagai bukti kemampuan organisasi publik untuk menyediakan sesuatu yang menjadi tuntutan seluruh rakyat di suatu negara. Maka dari itu responsivitas merupakan cara yang efesien untuk mengatur urusan dalam memberikan pelayanan kepada masyarakat baik ditingkat pusat maupun tingkat daerah atau lokal. Dalam hal ini, baik pemerintah pusat maupun daerah dapat dikatakan responsif terhadap kebutuhan masyarakat apabila kebutuhan masyarakat diidentifikasi oleh para pembuat kebijakan dengan pengetahuan yang dimiliki secara tepat dan dapat menjawab apa yang menjadi kepentingan publik (Widodo dalam Aprilya (2019)).

\section{KERANGKA PIKIR}

Kerangka pikir menggambarkan konsep penelitian mengenai responsivitas penyelenggaraan pelayanan publik di Dinas Kependudukan dan Pencatatan Sipil Kabupaten Bone dengan tujuan untuk mengetahui bagaimana keenam indikator yang diteliti penulis diterapkan di Dinas Kependudukan dan Pencatatan Sipil Kabupaten Bone. Selain itu untuk menjawab rumusan masalah penelitian dan mencapai tujuan dari penelitian yang akan dilakukan.

Dalam penelitian ini, peneliti mengkaji indikator responsivitas yang dikemukakan oleh Zeithaml dkk, sebagai berikut: 1) Kemampuan Merespon Masyarakat, 2) Kecepatan Melayani, 3) Ketepatan Melayani, 4) Kecermatan Melayani, 5) Ketepatan Waktu Pelayanan, dan 6) Kemampuan menanggapi Keluhan. Berdasarkan uraian diatas, peneliti menyusun bagan kerangka pikir penelitian, sebagai berikut 


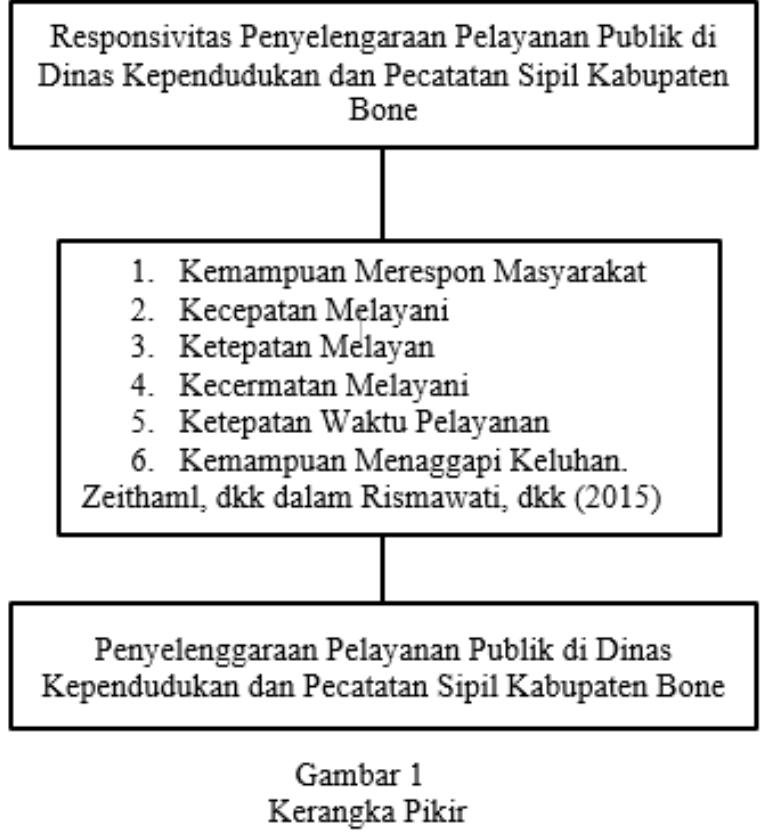

\section{METODE PENELITIAN}

\section{Tipe Penelitian}

Penelitian ini menggunakan jenis penelitian kualitatif yang bersifat deskriptif. Penelitian kualitatif adalah penelitian yang dengan menggunakan teknik menyelidiki, menemukan dan menggambarkan serta menjelaskan kualitas maupun keistimewaan dari responsivitas penyelanggaraan pelayanan publik di Dinas Kependudukan dan Pecatatan Sipil Kabupaten Bone.

\section{Sumber Data dan Teknik Pengumpulan Data}

Sumber data yang digunakan dalam penelitian ini ada dua cara yaitu: pertama data primer, yaitu data yang diperoleh melalui hasil penelitian langsung terhadap objek yang diteliti. Data tersebut diperoleh melalui wawancara dari informan. Kedua data sekunder yaitu data-data yang diperoleh dari buku-buku, dokumen-dokumen, peraturan-peraturan, tulisan-tulisan, dan kinerja yang dianggap relevan dengan penelitian ini. Teknik pengumpulan data yang digunakan yakni wawancara, observasi dan dokumentasi.

\section{Informan Penelitian}

Informan dalam penelitian kualitatif merupakan orang yang di pandang mengetahui permasalahan yang akan dikaji yaitu responsivitas penyelanggaraan pelayanan publik di Dinas Kependudukan dan Catatan Sipil Kabupaten Bone dan bersedia untuk memberikan 
informasi kepada peneliti. Adapun informan dalam penelitian ini berasal dari aparat pemerintah pada Dinas Kependudukan dan Pencatatan Sipil yaitu tiga orang serta masyarakat lima orang yang secara langsung merasakan dan melihat bagaimana responsivitas penyelenggaraan pelayanan publik di Dinas Kependudukan dan Pecatatan Sipil Kabupaten Bone.

\section{Teknik Analisis Data}

Dalam suatu peneltian, analisis data adalah tahapan yang dilakukan peneliti sejak berada di lapangan dan setelah selesai melakukan penelitian di lapangan. Aktivitas dalam analisis data kualitatif dilakukan secara interaktif dan berlangsung terus menerus hingga tuntas, sehingga datanya sudah mejadi jenuh. Tahapan analisis data yang dilakukan sesuai dengan tahapan analisis data meliputi pengumpulan data, reduksi data, penyajian data serta penarikan kesimpulan.

\section{Hasil dan Pembahasan}

Responsivitas Penyelenggaraan Pelayanan Publik di Dinas Kependudukan dan Pencatatan Sipil Kabupaten Bone, merujuk kepada indikator yaitu: Kemampuan Merespon Masyarakat, Kecepatan Melayani, Ketepatan Melayani, Kecermatan Melayani, Ketepatan Waktu Pelayanan, Kemampuan Menaggapi Keluhan. Inilah yang menjadi dasar Responsivitas Penyelenggaraan Pelayanan Publik di Dinas Kependudukan dan Pecatatan Sipil Kabupaten Bone.

\section{Kemampuan Merespon Masyarakat}

Menurut Syahruddin et al (2020) pelayanan publik saat ini menjadi bagian kebutuhan setiap masyarakat dan setiap birokrasi publik perlu berupaya untuk memberikan kualitas pelayanan yang terbaik kepada masyarakat pengguna. Maka dari itu, Dinas Kependudukan dan Pencatatan Sipil Kabupaten Bone harus mampu melaksanakan tugasnya secara baik, berkomunikasi dengan baik dan sopan terhadap masyarakat, memahami apa yang menjadi kebutuhan dari masyarakat Bone dan melakukan pembenahan dalam hal pelayanan sebagai bentuk peningkatan respon terhadap masyarakat.

Dari hasil penelitian yang didapatkan peneliti dapat dsimpulkan bahwa, dalam Responsivitas Penyelenggaraan Pelayanan Publik di Dinas Kependudukan dan 
Pencatatan Sipil Kabupaten Bone tidak terjadi permasalahan yaitu kurangnya respon atau tanggapan para pelayanan publik dalam melayani masayarakat.

Dinas Kependudukan dan Pencatatan Sipil Kabupaten Bone telah melaksanakan tugasnya secara baik, berkomunikasi dengan baik dan sopan terhadap masyarakat yang mengurus dokumen kependudukan. Dapat dilihat dari yang pertama nomor handphone kepala Dinas Kependudukan dan Pencatatan Sipil Kabupaten Bone adalah nomor publik sehingga masyarakat dengan bebas dapat berkomunikasi langsung dengan kepala dinas, kemudian Dinas Kependudukan dan Pencatatan Sipil Kabupaten Bone buka komunikasi lewat live di RRI Bone dan RRI Swasta, minimal dua kali sebulan.

Berdasarkan pernyataan tersebut, peneliti menyelidiki mengenai live di RRI, sehingga ditemukan bahwa live RRI ini bernama Radio Kebanggaan Masyarakat Bone SUARA BONE BERADAT yang berfrekuensi 97,7 FM. Radio Suara Bone Beradat memiliki fungsi sebagai media penyebaran informasi timbal balik antara pemerintah daerah dan masyarakat.

2. Kecepatan Melayani

Kecepatan melayani yaitu pelayanan administrasi harus sesuai dengan waktu yang telah ditentukan sesuai dengan Standar Operasional Prosedur atau SOP. Jika sesuai SOP Dinas maka waktu pelayanan memakan waktu selama tiga hari, tetapi apabila dalam jangka waktu tersebut pelayanan belum juga selesai maka masyarakat diminta langsung menemui kepala dinas menanyakan permasalahan pelayanan yang belum selesai. Jika mengenai kecepatan waktunya sesuai dengan standar SOP, pertama itu penginputan KTP maka kita input dulu NIK, kadangkadang penginputan NIK itu memakan waktu kurang dari 5 menit. Setelah itu diproses dokumennya, setelah itu diverifikasi, kemudian ditandatangani, lalu dikirim ke pusat kemudian ditandatangani. Setelah ditandatangani kemudian print out. Namun, waktu pelayanan biasa terganggu akibat jaringan yang kurang baik sehingga waktu pelayanan juga terhambat dan tidak mampu menyelesaikan administrasi sesuai dengan waktu yang telah ditentukan karena faktor jaringan eror. Kemudian masalah selanjutnya kurang cepat dalam hal melayani dikarenakakan karena lebih banyak yang harus dilayani dibandingkan dengan aparatur pemeintahan yang ada di sana sehingga harus menunggu atau melakukan antrian 
yang cukup lama.

Menurut Zeithaml, dkk dalam Rismawati, dkk (2015) menjelaskan secara rinci bahwa responsivitas termasuk kedalam salah satu dimensi kualitas pelayanan publik, yang salah satunya yaitu pelayanan yang cepat dimaksudkan dengan meliputi kesigapan dan ketulusan petugas dalam menjawab pertanyaan atau permintaan dari masyarakat. Maka dari itu, Dinas Kependudukan dan Pencatatan Sipil Kabupaten Bone harus mampu menyediakan pelayanan yang cepat dimaksudkan dengan meliputi dengan penimalisiran penyebab-penyebab dari keterlambatan pelayanan dan perbaikan saran dan prasana yang mendukung kecepatan pelayanan.

3. Ketepatan Melayani

Dinas Kependudukan dan Pecatatan Sipil Kabupaten Bone dalam hal ketepatan pelayanan telah memberikan sarana berupa loket untuk para pengurus dokumen kependudukan, sesuai dengan Standar Operasional Prosedur atau SOP yang berlaku, ketika online maka menunggu resi kemudian di bawah ke Dinas Kependudukan dan Pecatatan Sipil Kabupaten Bone. Ada tahapan-tahapan yang perlu diperhatikan dalam pengurusan dan harus melengkapi semua persyaratan.

Dalam satu dokumen kadang-kadang memakan waktu sampai sepuluh menit. Kemudian dalam satu hari kerja itu ada tujuh jam kerja, dalam tujuh jam itu berapa menit itu kalkulasinya. Makanya kalau terlalu banyak pelayanan maka Dinas membuat pelayanan tiga hari kerja maksimalnya.

Dinas Kependudukan dan Pecatatan Sipil Kabupaten Bone telah meningkat dari tahun ke tahun dalam hal ketepatan melayani. Sehingga ukuran keberhasilan penyelenggaraan pelayanan ditentukan oleh tingkat kepuasan penerima pelayanan yaitu masyarakat. Kepuasan penerima pelaynanan dicapai apabila penerima pelayanan memperoleh pelayanan sesuai dengan apa yang diharapkan.

4. Kecermatan Melayani

Kecermatan dalam memberikan pelayanan perlu diperhatikan agar tidak terjadi kesalahan yang bisa merugikan masyarakat. Pelayanan dengan cermat yaitu petugas selalu fokus dan sungguh-sungguh dalam melakukan penyampaian pelayanan serta dalam melayani kebutuhan masyarakat, berikut pembahasan dari hasil penelitian sebagai berikut.

Semua operator sudah terhubung ke server, ada proses atau tahapan yang 
perlu dilakukan berupa pencocokan data, umpama ada yang beda satu huruf atau beda spasi tidak bisa digunakan. Walaupun satu huruf itu tetap bermasalah, sehingga harus hati-hati dalam menginput data, kemudian dalam penginputan perlu adanya lampiran, contoh melampirkan kartu keluarga. Untuk menginput data baru harus dicek apakah tidak ganda, pemborosan apabila diterbitkan jika datanya ganda. Di dalam penerbitan dokumen itu NIK yang menjadi acuan dan setelah itu ada uji validitas yang dilakukan oleh Dinas Kependudukan dan Pencatatan Sipil Kabupaten Bone. Pencocokan data perlu dilakukan, ketelatenan dan profesionalitas Dinas Kependudukan dan Pencatatan Sipil Kabupaten Bone dalam menjalankan tugasnya sudah baik. hal ini merupakan bagian dari pelayanan publik.

Kedisiplinan dan ketaatan serta pelayanan dengan menggunakan atau berbasis elektronik sudah diterapkan menambah kecermatan pelayanan yang diberikan oleh Dinas Kependudukan dan Pencatatan Sipil Kabupaten Bone. Sehingga dalam prinsip pokok dalam pelayanan publik menurut Irfan Islamy (1999) menjelaskan prinsip teknikalitas, yaitu bahwa setiap jenis pelayanan proses pelayanannya itu harus ditangani oleh aparat yang benar-benar memahami secara teknis pelayanan tersebut berdasarkan kejelasan, ketepatan, dan kemantapan sistem, prosedur serta instrumen pelayanan.

5. Ketepatan Waktu Pelayanan

Maksud dari pelayanan dengan waktu yang tepat yaitu petugas dalam melayani masyarakat diharapkan pelaksanaan pelayanannya dapat diselesaikan dalam kurun waktu yang telah ditentukan, berikut pembahasannya.

Standar Operasional Prosedur (SOP) tersebut dilengkapi dengan ketentuan jadwal penerimaan berkas permohonan dokumen kependudukan dan pencatatan sipil sebagai berikut: 1. Hari : Senin - Kamis Pagi : 08.15 - 11.30 WITA Siang : 13.15 - 15.00 WITA 2. Hari : Jumat Pagi : 08.15 - 11.30 WITA Siang : 13.30 15.00 WITA 3. Norma waktu penyelesaian pekerjaan dokumen kependudukan adalah maksimal 3 (tiga) hari.

Ketepatan waktu pelayanan harus sesuai dengan SOP yang telah ditetapkan di Dinas Kependudukan dan Pencatatan Sipil Kabupaten Bone bahwa ada standar yang harus dipatuhi dan dijalankan, waktu proses sampai verifikasi harus sesuai jadwal.

Melakukan proses pelayanan kepada masyarakat harus memiliki sikap 
disiplin dan profesional sesuai dengan tugas pokok dan fungsinya masing-masing. Namun, bahwa ketepatan waktu melayani belum maksimal karena aparat atau petugas yang menjadi pelayanan yang jumlahnya sedikit dibandingkan masyarakat yang banyak.

6. Kemampuan Menanggapi Keluhan

Setiap pimpinan unit penyelenggara pelayanan publik wajib dalam menyelesaikan setiap laporan atau pengaduan maupun keluhan masyarakat mengenai ketidakpuasan dalam pemberian pelayanan sesuai dengan kewenangannya. Hal ini dilakukan agar supaya masyarakat dapat memperoleh kepastian waktu pelayanan yang akan diterimanya. Selain itu, dengan menanggapi pengaduan masyarakat, masyarakat akan merasa puas dengan pelayanan karena mendapatkan feedback yang baik. Berikut pembahasan dari hasil penelitian dalam wawancara tentang menanggapi keluhan masyarakat dalam pemberian pelayanan sebagai berikut.

Kemampuan menanggapi keluhan yang dilakukan tersebut dengan cara membuka komunikasi kepada masyarakat melalui bertemu langsung kepada kepala dinas dan melalui nomor telepon/kontak kepala dinas. Mekanisme komplain melalui penggunaan website maupun aplikasi pengaduan pelayanan untuk masyarakat belum diterapkan oleh Dinas Kependudukan dan Pencatatan Sipil kabupaten Bone dikarenakan adanya alasan dan kendala tertentu.

Menurut Tjiptono dalam Rukmana (2019) menyebutkan bahwa responsivitas (daya tanggap) merupakan keinginan para staf untuk membantu pelanggan dalam memberikan pelayanan dengan tanggap. Sehingga dapat disimpulkan bahwa Dinas Kependudukan dan Pencatatan Sipil Kabupaten Bone telah memiliki daya tanggap yang baik karena membantu pelanggan dalam memberikan pelayanan, menanggapi keluhan, mencocokan data-data masyarakat, mengupayakan penyelesaian permasalahan yang harus sesuai dengan SOP.

\section{KESIMPULAN}

Berdasarkan hasil penelitian dan pembahasan maka dapat ditarik kesimpulan bahwa responsivitas penyelenggaraan pelayanan publik di Dinas Kependudukan dan Pencatatan Sipil Kabupaten Bone sudah baik. Hal ini dapat dilihat dari beberapa indikator yang sudah dijelaskan sebelumnya yaitu: 
1. Kemampuan Merespon Masyarakat yaitu Dinas Kependudukan dan Pencatatan Sipil Kabupaten Bone telah melaksankan tugasnya secara baik, berkomunikasi dengan baik dan sopan terhadap masyarakat yang mengurus dokumen kependudukan. Dapat dilihat dari yang pertama nomor handphone kepala Dinas Kependudukan dan Pencatatan Sipil Kabupaten Bone adalah nomor publik sehingga masyarakat dengan bebas dapat berkomunikasi langsung dengan kepala dinas, kemudian Dinas Kependudukan dan Pencatatan Sipil Kabupaten Bone buka komunikasi lewat live di RRI Bone dan RRI Swasta, minimal dua kali sebulan.

2. Kecepatan Melayani yaitu waktu pelayanan biasa terganggu akibat jaringan yang kurang baik sehingga waktu pelayanan juga terhambat dan tidak mampu menyelesaikan administrasi sesuai dengan waktu yang telah ditentukan karena faktor jaringan eror. Kemudian masalah selanjutnya kurang cepat dalam hal melayani dikarenakakan lebih banyak yang harus dilayani dibandingkan dengan aparatur pemeintahan yang ada di sana.

3. Ketepatan Melayani yaitu waktu pelayanan harus sesuai dengan SOP yang telah ditetapkan di Dinas Kependudukan dan Pencatatan Sipil Kabupaten Bone bahwa ada standar yang harus dipatuhi dan dijalankan, waktu proses sampai verifikasi harus sesuai jadwal. Melakukan proses pelayanan kepada masyarakat harus memiliki sikap disiplin dan profesional sesuai dengan tugas pokok dan fungsinya masingmasing.

4. Kecermatan Melayani yaitu semua operator sudah terhubung ke server, ada proses atau tahapan yang perlu dilakukan berupa pencocokan data kemudian penginputan.

5. Ketepatan Waktu Pelayanan yaitu standar yang harus dipatuhi dan dijalankan, waktu proses sampai verifikasi harus sesuai jadwal dan melakukan proses pelayanan kepada masyarakat harus memiliki sikap disiplin dan profesional sesuai dengan tugas pokok dan fungsinya masing-masing.

6. Kemampuan Menaggapi Keluhan yaitu Dinas Kependudukan dan Pencatatan Sipil Kabupaten Bone menerima pengaduan kemudian dan mengisi Google Form serta mengupayakan penyelesaian permasalahan yang harus sesuai dengan SOP. Penyebab keluhan masyarakat yaitu jaringan dan ketika print out yang menjadi permasalahan maka jaringan tersebut harus dilakukan perbaikan. 


\section{SARAN}

Adapun saran yang dapat dikemukakan yang didasari oleh kesimpulan sebelumnya yaitu:

1. Mengusahakan percepatan perbaikan jaringan, sehingga menjaga situasi tetap kondusif dalam pelayanan administrasi kependudukan.

2. Dinas Kependudukan dan Pencatatan Sipil Kabupaten Bone khususnya pada pegawai loket pelayanan harus mampu meningkatkan responsivitasnya kepada masyarakat dengan cara memperhatikan waktu pelayanan.

\section{DAFTAR PUSTAKA}

Aprilya, S. (2019). Responsivitas dan Pelayanan Publik di Kantor Dinas Kependudukan dan Pencatatan Sipil Kabupaten Gowa. Ilmu Administrasi Negara.

Herdini, F., \& Widiyarta, A. (2020). Responsivitas Pelayanan Publik Dalam Menangani $\underline{\text { Keluhan Pelanggan di Perusahaan Daerah Air Minum (PDAM) Kabupaten Nganjuk. }}$ $\underline{1-9 .} \underline{(2)}$

Kairupan, J. K. (2015). Pengaruh Reformasi Birokrasi Terhadap Kualitas Pelayanan Publik

Di Dinas Kependudukan Dan Catatan Sipil Kabupaten Minahasa Utara. Jurnal Administrasi Publik UNSRAT, 4(35), 1468.

Kartini, N. M., Mahsyar, A., Ma, A., Negara, I. A., Makassar, U. M., Negara, I. A., Makassar, U. M., Negara, I. A., \& Makassar, U. M. (2020). Inovasi Pelayanan Publik Papa Sehat di SDN 81 Kalukubodo Kabupaten Takalar. 1.

Mahsyar, A. (2011). Masalah Pelayanan Publik Di Indonesia Dalam Perspektif Administrasi Publik. I(2), 81-90.

Nurdin, N. H. (2019). Optimalisasi Pelayanan Publik Dalam Perspektif New Publick Service Pada Badan Pendapatan Daerah Kota Makassar. Jurnal Ilmiah Pranata Edu, 1(1), 01-13. https://doi.org/10.36090/jipe.v1i1.188

Pasal 1 Ayat 1 Undang-Undang Nomor 25 Tahun 2009 Tentang Pelayanan Publik.

Rismawati, Madani, M., \& Rahim, S. (2015). Responsivitas pelayanan perceraian kantor pengadilan agama sengkang kabupaten wajo. 1. (2) (3)

Rukmana, N. S. (2019). Responsivitas Pelayanan Publik Dalam Pengurusan Surat Izin

Usaha Perdagangan Di Dinas Penanaman Modal Dan Pelayanan Terpadu Satu Pintu (Dpmptsp) Kabupaten Sinja. Journal of Chemical Information and Modeling, 53(9), 1689-1699. 
Suwanda, R. M. dan dadang. (2019). Good Governance Pengelolaan Keuangan Daerah (Yudi Prihanto Santoso (ed.)).

Syahruddin, N. I., Andriansyah, \& Prasetyo, A. J. (2020). Penerapan Kypso Dalam Pelayanan Publik Sebagai Perwujudan New Public Service Paradigma. 322-346. 